\title{
Nitroarene Compound
}

National Cancer Institute

\section{Source}

National Cancer Institute. Nitroarene Compound. NCI Thesaurus. Code C44409.

Listed as "reasonably anticipated to be a human carcinogen" in Report on Carcinogens

(ROC), this group comprise a large class of structurally related chemicals that are normally found in particulate emissions from many combustion sources, most notably, diesel exhausts. Nitroarenes show genotoxic activity in a variety of in vitro and in vivo assays, and metabolic pathways for the creation of reaction products with the ability to cause gene mutations or changes in the structure of DNA have been described in tissues from animals as well as humans. (11th ROC from National Toxicology Prog ram) 